\title{
APLIKASI PENGELOLAAN INVENTARIS BARANG DI SMK NEGERI 1 PLAMPANG BERBASIS WEB
}

\author{
Yudi Mulyanto ${ }^{1)}$, Fery Ramdani ${ }^{2)}$ \\ 1) Informatika Universitas Teknologi Sumbawa \\ 2) Informatika Universitas Teknologi Sumbawa \\ email:yudi.mulyanto@uts.ac.id ${ }^{1)}$,feriramdhani9@gmail.com ${ }^{2}$ )
}

\begin{abstract}
Abstrak
Inventaris barang merupakan suatu kegiatan pencatatan barang sekaligus mengolah data-data persediaan barang yang dimiliki sebuah sekolah. Dalam institusi pendidikan, sarana dan prasarana sekolah sangat penting. Sarana dan prasarana berguna untuk menunjang penyelenggaraan proses belajar mengajar, baik secara langsung maupun tidak langsung dalam suatu institusi, untuk mencapai tujuan pendidikan. Pengelolaan data yang baik akan memberikan manfaat yang besar bagi kelancaran dan keberhasilan dalam kegiatan suatu organisasi.

Rumusan masalah: Bagaimana merancang dan membangun Aplikasi Pengelolaan Inventaris Barang Di SMK Negeri 1 Plampang? Sedangkan tujuan: Untuk merancang dan membangun Aplikasi Pengelolaan Inventaris Barang Di SMK Negeri 1 Plampang. Metode Penelitian: Deskriptif dengan pendekatan kualitatif. Adapun metode pengumpulan data yang digunakan adalah observasi, wawancara, dan studi pustaka. Metode pengembangan perangkat lunak yang digunakan dalam merancang Aplikasi Pengelolaan Inventaris Barang Di SMK Negeri 1 Plampang adalah waterfall. Sumber data yang digunakan adalah data primer dan data skunder.

Kesimpulan: Aplikasi ini dapat membantu karyawan tata usaha di SMK Negeri 1 Plampang dalam melakukan pengelolaan data barang seperti memudakan dalam pecarian data dan saat pembuatan laporan.
\end{abstract}

\section{Kata Kunci :}

Pengelolaan, Inventaris, Barang, SMK, Web.

\begin{abstract}
Inventory of goods is an activity of recording goods as well as processing data on inventory of goods owned by a school. In educational institutions, school facilities and infrastructure are very important. Facilities and infrastructure are useful to support the implementation of the teaching and learning process, both directly and indirectly in an institution, to achieve educational goals. Good data management will provide great benefits for smoothness and success in the activities of an organization. Research with the title "Application Inventory Management Application at Vocational School 1 Plampang". Problem formulation: How to design and build an Inventory Management Application in SMK Negeri 1 Plampang ?. Objective: To design and build an Inventory Management Application in SMK Negeri 1 Plampang. Research Methods: Descriptive with a qualitative approach. The data collection methods used are observation, interviews, and literature. The software development method used in designing the Inventory Management Application at SMK Negeri 1 Plampang is a waterfall. The data sources used are primary data and secondary data. Conclusion: This application can help employees of administration at SMK Negeri 1 Plampang in managing goods data such as fading in the search for data and when making reports.
\end{abstract}

Keywords : Management, Inventory, Goods, Vocational School, Web 


\section{Pendahuluan}

Perkembangan teknologi informasi menyebabkan terjadinya perubahan pola pikir manusia untuk memperoleh informasi secara cepat, tepat dan akurat. Teknologi komputer merupakan suatu teknologi yang sangat dibutuhkan oleh setiap organisasi, karena akan mengeluarkan suatu informasi yang akurat dan dapat digunakan dalam pengelolaan serta pencatatan inventaris barang.

Berdasarkan hasil observasi yang dilakukan di SMK Negeri 1 Plampang diperoleh informasi bahwa, pengelolaan inventaris di SMK Negeri 1 Plampang masih bersifat manual dengan menggunakan buku folio besar dalam pencatatan barang sehari-hari dan menggunakan aplikasi microsoft excel pada saat pelaporan.

Tujuan dari penelitian ini yaitu untuk merancang dan membangun aplikasi pengelolaan inventaris barang di SMK Negeri 1 Plampang. Batasan masalah dalam penelitian ini yaitu: penilitian ini dilakukan di SMK Negeri 1 Plampang, aplikasi ini hanya membahas pengelolaan inventaris barang di SMK Negeri 1 Plampang, bahasa pemrograman yang digunakan adalah PHP, program yang digunakan adalah Adobe Dreamweaver CS5., database yang digunakan adalah $M y S Q L$. dan database server yang digunakan adalah Xатрp. Jenis penelitian ini deskriptif dengan menggunakan pendekatan kualitatif. Metode pengumpulan data yang digunakan adalah: observasi, wawancara dan studi pustaka.

Penelitian mengenai sistem informasi inventaris pernah dilakukan Oleh Romadhon pada tahun (2014) yang berjudul "Sistem Informasi Pengelolaan Barang Inventaris Berbasis Desktop di SMK Negeri 1 Sungailiat". Dalam penelitian ini menghasilkan Informasi-informasi pengelolaan inventaris yang bermutu, seperti terhindarnya keteralambatan penyajian laporan dan kelengkapan pengelolaan inventaris yang disajikan pada laporan.

Diharapkan dengan adanya aplikasi ini dapat membantu bagian kepegawaiaan dalam mendata barang inventaris menjadi lebih cepat, tepat, dan akurat serta mudah dalam mengolah data dan membuat pelaporan kapanpun dibutuhkan.

\section{Tinjauan Pustaka}

Penelitian mengenai sistem informasi inventaris pernah dilakukan Oleh Romadhon pada tahun (2014) yang berjudul "Sistem Informasi Pengelolaan Barang Inventaris Berbasis Desktop di SMK Negeri 1 Sungailiat". Dalam penelitian ini menghasilkan Informasi-informasi pengelolaan inventaris yang bermutu, seperti terhindarnya keteralambatan penyajian laporan dan kelengkapan pengelolaan inventaris yang disajikan pada laporan.

Penelitian yang sama juga pernah dilakukan Oleh Nugroho pada tahun (2018) yang berjudul “ Pengembangan Sistem Informasi Inventaris Barang Berbasis Website di SMK Piri 2 Yogyakarta. Penelitian ini bertujuan untuk mempermudah pengelolaan barang di SMK Piri 2 Yogyakarta. Sistem informasi ini memiliki dua level pengguna yaitu Admin dan Pengguna.

Aplikasi adalah suatu bagian dari perangkat lunak yang dapat digunakan untuk menyelesaikan masalah-masalah yang khusus yang dihadapi user dengan menggunakan kemampuan komputer. ${ }^{4}$

Pengelolaan adalah serangkaian kegiatan untuk mencapai sasaran-sasaran tertentu dengan menggunakan orang-orang sebagai pelaksananya. ${ }^{6}$ Inventaris barang merupakan suatu kegiatan pencatatan barang sekaligus mengolah data-data persediaan barang yang dimiliki sebuah sekolah. Dalam institusi pendidikan, sarana dan prasarana sekolah sangat penting. Sarana dan prasarana berguna untuk menunjang penyelenggaraan proses belajar mengajar, baik secara langsung maupun tidak langsung dalam suatu institusi, untuk mencapai tujuan pendidikan. Pengelolaan data yang baik akan memberikan manfaat yang besar bagi kelancaran dan keberhasilan dalam kegiatan suatu organisasi. ${ }^{13}$ Web adalah sebuah sistem penyebaran informasi melalui internet. Informasi yang dikirimkan dapat berupa teks, suara (audio), animasi, gambar dan bahkan dalam format vidio yang dapat diakses melalui sebuah software yang disebut browser, seperti internet explorer, mozila firefox, opera dan lain-lain. ${ }^{2}$

\section{Metode Penelitian}

Jenis penelitian ini deskriptif dengan menggunakan pendekatan kualitatif. Metode pengumpulan data yang digunakan adalah: observasi, wawancara dan studi pustaka.

Metode pengembangan perangkat lunak yang digunakan dalam perancangan Aplikasi Pengelolaan Inventaris Barang di SMK Negeri 1 Plampang Berbasis Web ini adalah waterfall.

Berikut adalah tahapan-tahapan dalam penelitian skripsi dengan menggunakan metode waterfall sebagai metode pengembangan perangkat lunak:

1. Analisis Kebutuhan (Requirement analysis), pada tahap ini penulis melakukan analisis kebutuhan perangkat dan kebutuhan data dengan cara pengamatan secara langsung mengenai aplikasi pengelolaan inventaris barang yang akan dibuat.

2. Desain Sistem (System design), pada tahap desain sistem meliputi desain Unified Modeling Language, desain Interface atau tampilan antar muka sistem, dan desain database untuk aplikasi pengelolaan inventaris barang yang akan dibuat.

3. Pelaksanaan (Implementation), pada tahap ini dilakukan penulisan kode-kode program.

4. Integrasi dan Pengujian (Integration \& Testing), pada tahap ini dilakukan pengujian aplikasi dengan menggunakan metode pengujian perangkat lunak black box. Fungsi-fungsi yang diuji meliputi, pengujian halaman login user, halaman data barang, halaman barang masuk, halaman barang keluar, halaman pinjam barang, halaman stok barang, dan halaman laporan data barang.

5. Operasi dan Pemeliharaan (Operation \& Maintenance), pada tahap ini merupakan tahap akhir dimana aplikasi pengelolaan inventaris barang yang sudah selesai dibuat dan diserahkan ke pihak SMK Negeri 1 Plampang. Tahap ini adalah tahap perbaikan aplikasi sesuai dengan 
kebutuhan dan permintaan dari SMK Negeri 1 Plampang dan pada tahap ini juga dilakukan pembetulan jika terdapat kesalahan ataupun masalah yang ditemukan pada saat pengoperasian aplikasi.

Alat dan Bahan Penelitian

1. Analisa Kebutuhan Perangkat

a. Perangkat Keras (Hardware)

Adapun spesifikasi dari perangkat keras adalah:

1) Processor Dual-Core $2840 \mathrm{GHz}$

2) RAM 2 GB

3) Harddisk 500 GB

b. Perangkat lunak (Software)

Adapun perangkat lunak yang digunakan adalah :

1) Sistem Operasi Windows $7 /$ Windows $8 /$ Windows 10

2) MySQL Database

3) Adobe Dreamweaver CS5

4) Web Browser

5) Xampp

6) PHP

2. Analisa Kebutuhan Data

Kebutuhan data dalam melakukan penelitian ini adalah data primer dan data sekunder yaitu :

a. Data Primer adalah data yang diperoleh langsung dari bagian tata usaha SMK Negeri 1 Plampang.

b. Data Sekunder adalah data yang diperoleh dengan membaca dan mempelajari referensi yang berkaitan dengan penelitian yang dilakukan.

\section{Hasil dan Pembahasan}

Hasil dari pengumpulan data yang telah dilakukan dalam penelitian ini adalah sebagai berikut:

1. Observasi

Setelah melakukan observasi pada SMK Negeri 1 Plampang, maka sekolah tersebut menyetujui dijadikan objek penelitian guna membangun aplikasi pengelolaan inventaris barang untuk memudahkan pekerjaan bagian tata usaha dalam mengelolah data inventaris barang yang ada di SMK Negeri 1 Plampang yang selama ini masih bersifat manual dan tertulis di buku pencatatan barang.

2. Wawancara

Pada tahap wawancara dilakukan dengan wawancara langsung dan memberikan pertanyaan langsung kepada pihak sekolah yaitu bapak Febry Wahyudi, S.Pd selaku karyawan tata usaha di SMK Negeri 1 Plampang. Dari wawancara yang dilakukan dengan bapak Febry Wahyudi, S.Pd. Diketahui bahwa pihak sekolah belum memiliki sistem untuk pengelolaan inventaris barang, sehingga penelitian diharapkan dapat membantu pihak sekolah untuk mengelola data inventaris barang di SMK Negeri 1 Plampang. Hasil dari wawancara yang dilakukan dengan bapak Febry Wahyudi, S.Pd terdapat di lampiran.

3. Studi Pustaka

Pada tahap studi pustaka ini peneliti mengumpulkan data dari dokumen-dokumen yang berada di SMK Negeri 1 Plampang yaitu dalam bentuk buku pencatatan barang.Bagian Hasil dan Pembahasan merupakan bagian yang memuat semua temuan ilmiah yang diperoleh.

\section{Hasil Analisis Kebutuhan}

Adapun hasil dari analisis kebutuhan dalam membangun Aplikasi Pengelolaan Inventaris Barang di SMK Negeri 1 Plampang sebagai berikut:

1. Kebutuhan Perangkat Keras (Hardware) Adapun perangkat keras yang digunakan untuk pembuatan Aplikasi Pengelolaan Inventaris Barang di SMK Negeri 1 Plampang sebagai berikut:

Tabel 1 Spesifikasi Perangkat Keras (Hardware)

\begin{tabular}{|l|l|}
\hline \multicolumn{1}{|c|}{ Nama Perangkat } & \multicolumn{1}{|c|}{ Spesifikasi } \\
\hline Laptop & $\begin{array}{l}\text { Processor Intel Core i3 1.90 } \\
\mathrm{GHz}\end{array}$ \\
\hline & RAM 6 GB \\
\hline & Harddisk 500 GB \\
\hline
\end{tabular}

2. Kebutuhan Perangkat Lunak (Software)

Adapun perangkat lunak yang digunakan untuk pembuatan Aplikasi Pengelolaan Inventaris Barang di SMK Negeri 1 Plampang sebagai berikut:

Tabel 2 Spesifikasi Perangkat Lunak (Software)

\begin{tabular}{|c|l|l|}
\hline No & Perangkat Lunak & \multicolumn{1}{|c|}{ Spesifikasi } \\
\hline 1 & Sistem Operasi & Windows 10 \\
\hline 2 & Database Server & Xampp \\
\hline 3 & Web Browser & $\begin{array}{l}\text { Google } \\
\text { Chrome/Mozilla } \\
\text { Firefox }\end{array}$ \\
\hline 4 & $\begin{array}{l}\text { Bahasa } \\
\text { Pemrograman }\end{array}$ & PHP \\
\hline 5 & Aplikasi & $\begin{array}{l}\text { Adobe Dreamweaver } \\
\text { CS5 }\end{array}$ \\
\hline
\end{tabular}

3. Kebutuhan Data

Pada penelitian ini, penulis membutuhkan beberapa data untuk mengelolah aplikasi ini.

Data tersebut diperlukan untuk membuat sebuah basis data yang berfungsi untuk mengelolah data-data inventaris barang pada SMK Negeri 1 Plampang. Adapun kebutuhan data pada pengelolaan data inventaris barang yaitu data barang habis pakai maupun data barang tidak habis pakai yang telah di tulis di dalam buku pencatatakan barang.

\section{Perancangan Sistem}

Adapun perancangan sistem dari pembuatan Aplikasi Pengelolaan Inventaris Barang di SMK Negeri 1 Plampang sebagai berikut:

1. Use Case Diagram

Adapun Use Case Diagram dari Pengelolaan data inventaris barang pada SMK Negeri 1 Plampang. 


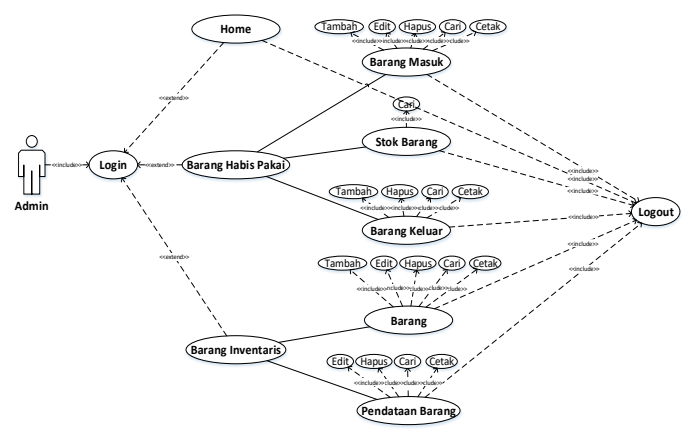

Gambar 1 Use Case Diagram Pengelolaan data inventaris barang pada SMK Negeri 1 Plampang

Aktor dalam gambar di atas adalah Pegawai Tata Usaha yang bertindak sebagai admin. Admin memiliki hak akses penuh untuk mengelolah seluruh data dalam aplikasi. Hak akses yang dimiliki oleh admin adalah mengelola data barang habis pakai yang meliputi barang masuk, stok barang, barang keluar dan data barang inventaris yang meliputi barang, dan pendataan barang dengan berbagai aksi seperti menambah data , mengedit data, menghapus data, mencari dan , serta mencetak.

\section{Activity Diagram}

Adapun Activity Diagram yang memodelkan proses-proses yang terjadi pada Use case Diagram, Berikut adalah Activity Diagram dari Aplikasi Pengelolaan Inventaris Barang pada SMK Negeri 1 Plampang.

a. Activity Diagram Login

Activity Diagram saat admin melakukan login.

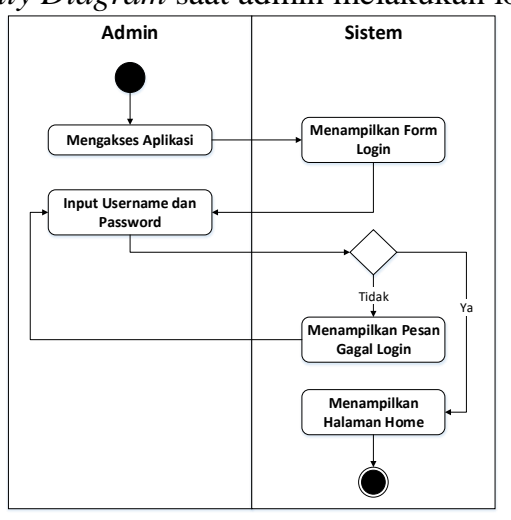

Gambar 2 Activity Diagram Login

Pada saat admin mengakses aplikasi, sistem akan menampilkan form login. Pada form login, admin dapat mengisi username dan password, setelah admin mengisi username dan password, sistem akan melakukan pengecekan username dan password. Apabila username dan password tersebut benar, maka akan diproses menuju halaman home dan apabila username dan password tersebut salah maka akan tampil pesan gagal login.

b. Activity Diagram Barang Masuk

Activity Diagram saat admin melakukan pengelolaan barang masuk.

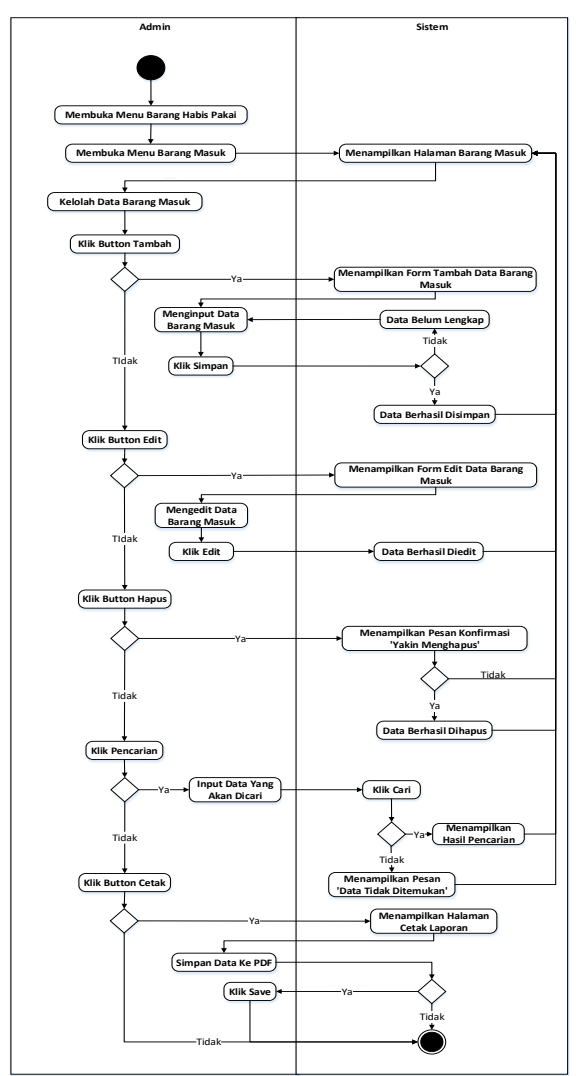

Gambar 3 Activity Diagram Barang Masuk

Proses ini dimulai pada saat admin membuka menu barang masuk pada menu barang habis pakai, sistem akan menampilkan halaman barang masuk dan admin dapat mengelolah data barang masuk seperti menambah data, mengedit data, menghapus data, mencari data, dan mencetak data.

c. Activity Diagram Stok Barang Activity Diagram saat admin melakukan pengelolaan stok barang.

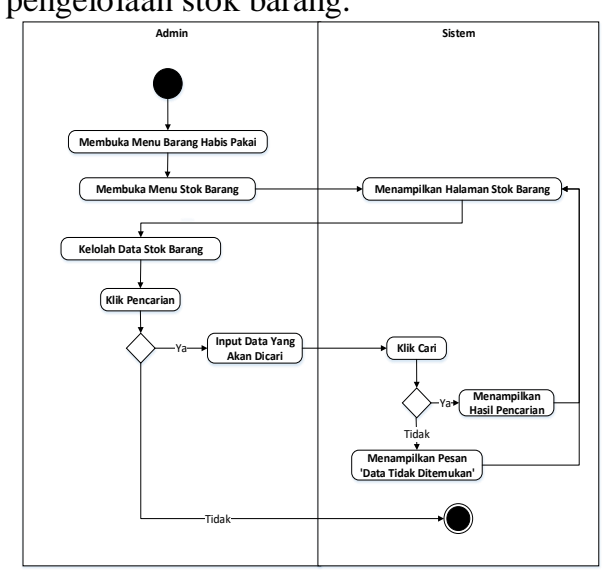

Gambar 4 Activity Diagram Stok Barang

Proses ini dimulai pada saat admin membuka menu stok barang pada menu barang habis pakai, sistem akan menampilkan halaman stok barang dan admin hanya dapat mengelolah data seperti mencari data.

d. Activity Diagram Barang Keluar Activity Diagram saat admin melakukan pengelolaan barang keluar. 


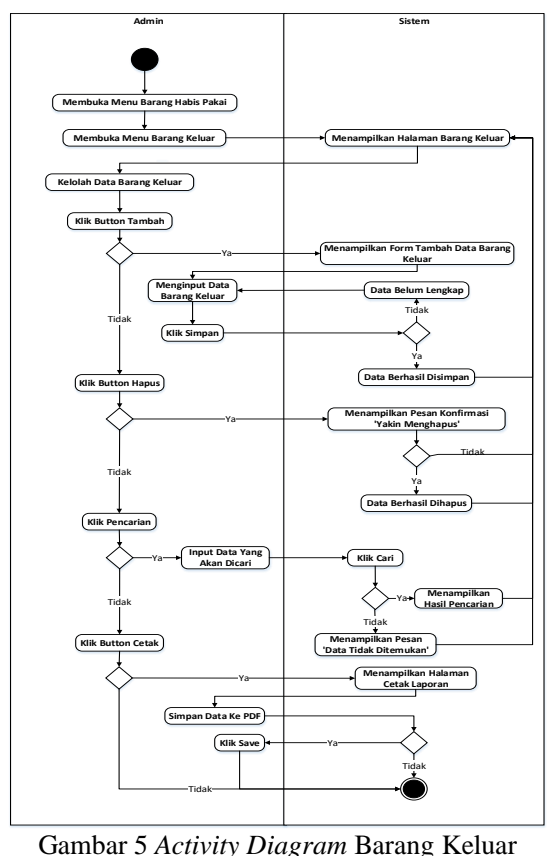

Proses ini dimulai pada saat admin membuka menu barang keluar pada menu barang habis pakai, sistem akan menampilkan halaman barang keluar dan admin dapat mengelolah data barang keluar seperti menambah data, menghapus data, mencari data, dan mencetak data.

e. Activity Diagram Barang

Activity Diagram saat admin melakukan pengelolaan barang.

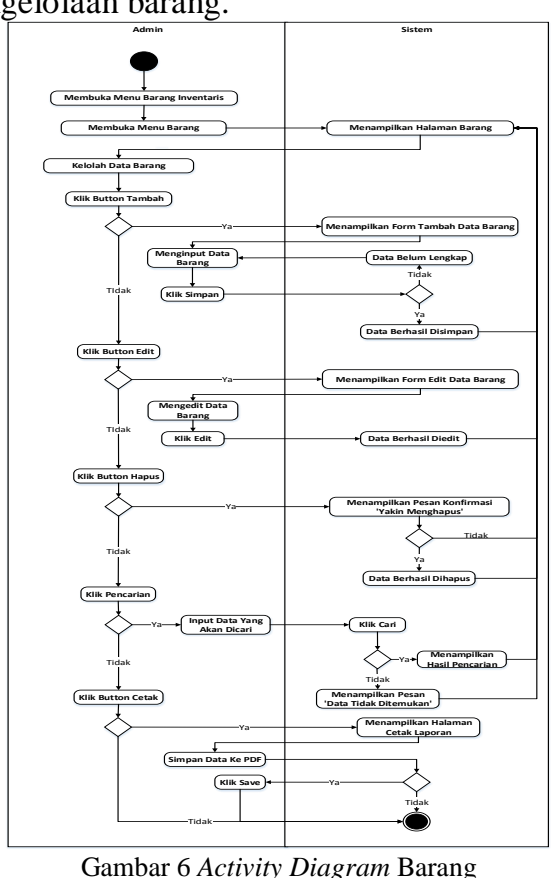

Proses ini dimulai pada saat admin membuka menu barang pada menu barang inventaris, sistem akan menampilkan halaman barang dan admin dapat mengelolah data barang seperti menambah data, mengedit data, menghapus data, mencari data, dan mencetak data.

f. Activity Diagram Pendataan Barang Activity Diagram saat admin melakukan pengelolaan pendataan barang.

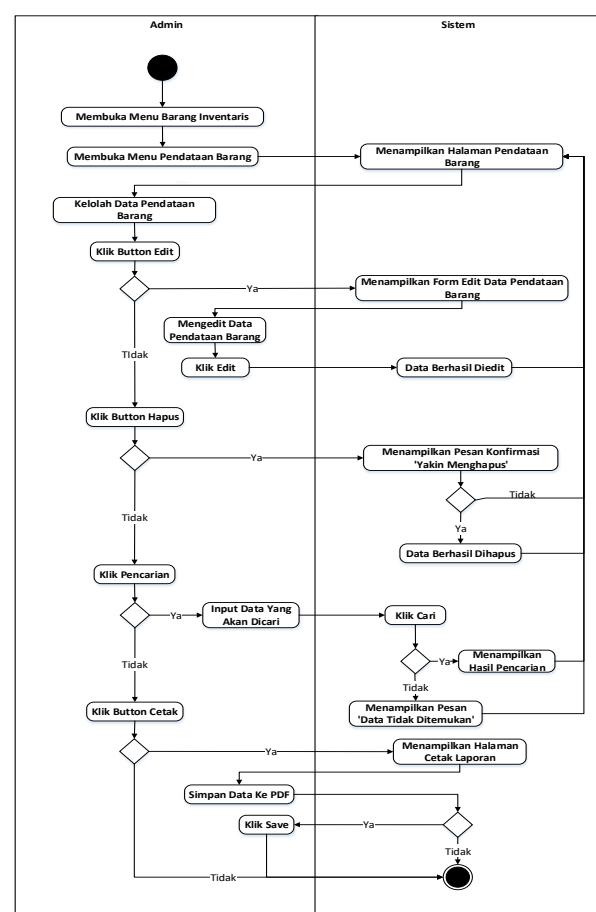

Gambar 7 Activity Diagram Pendataan Barang Proses ini dimulai pada saat admin membuka menu pendataan barang pada menu barang inventaris, sistem akan menampilkan halaman pendataan barang dan admin dapat mengelolah data pendataan barang seperti mengedit data, menghapus data, mencari data, dan mencetak data.

\section{Sequence Diagram}

Squence Diagram menjelaskan permodelan sistem yang akan dibangun untuk menggambarkan interkasi antara objek yang telah disusun dan merupakan tahap proses dari Usecase Diagram dan Activity Diagram.

a. Sequence Diagram Login

Berikut adalah bentuk sequance diagram login dari Aplikasi Pengelolaan Inventaris Barang Pada SMK Negeri 1 Plampang.

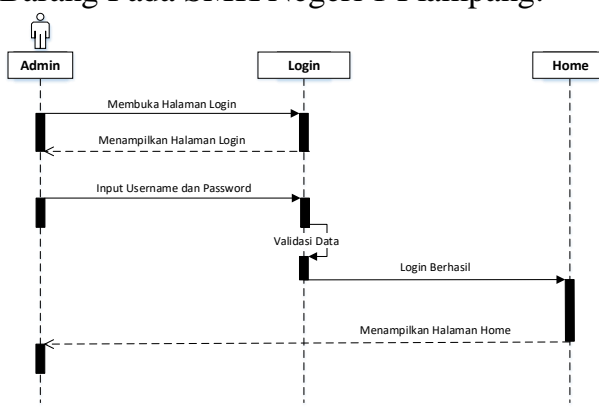

Gambar 8 Sequence Diagram Login

Proses ini dimulai pada saat admin membuka dan mengakses aplikasi, maka sistem akan menampilkan tampilan halaman login. Lalu admin memasukkan username dan password untuk dapat mengelolah aplikasi. Selanjutnya dilakukan pengecekkan validasi data yang dimasukkan. Apabila login berhasil maka akan tampil halaman home. 
b. Sequence Diagram Barang Masuk

Berikut adalah bentuk sequance diagram barang masuk dari Aplikasi Pengelolaan Inventaris Barang Pada SMK Negeri 1 Plampang.

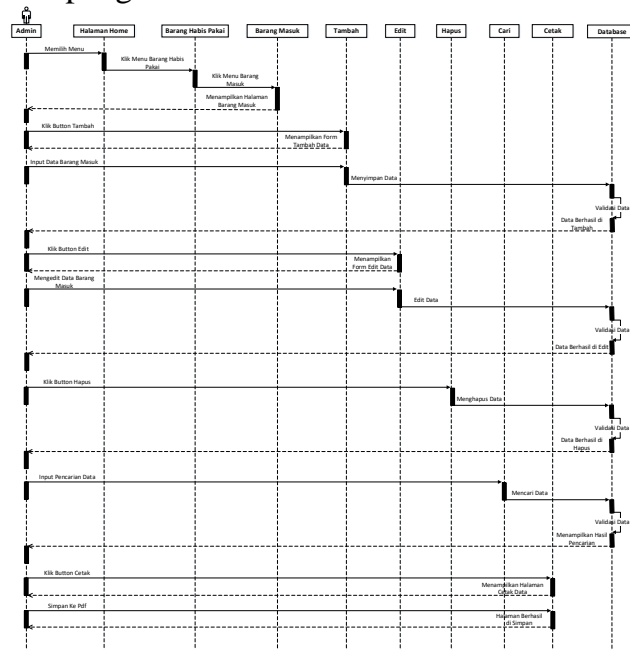

Gambar9 Sequence Diagram Barang Masuk

Proses ini dimulai ketika admin membuka halaman barang masuk dari barang habis pakai, maka sistem akan menampilkan halaman barang masuk. Lalu admin dapat mengelolah data dari barang masuk seperti menambah data, mengubah data, menghapus data, mencari data, dan mencetak data.

c. Sequence Diagram Stok Barang

Berikut adalah bentuk sequance diagram stok barang dari Aplikasi Pengelolaan Inventaris Barang Pada SMK Negeri 1 Plampang.

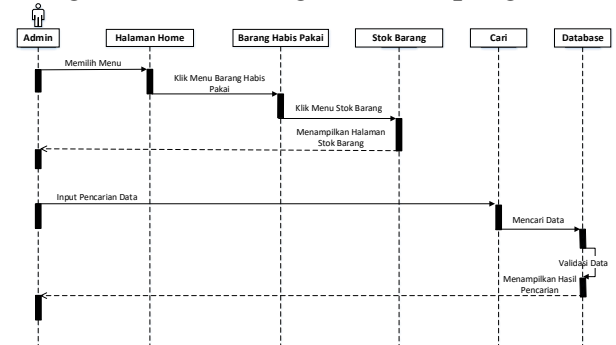

Gambar 10 Sequence Diagram Stok Barang

Proses ini dimulai ketika admin membuka halaman stok barang dari barang habis pakai, maka sistem akan menampilkan halaman stok barang. pada halaman stok barang ini admin hanya dapat mengelolah data dengan melakukan pencarian data saja.

d. Sequence Diagram Barang Keluar

Berikut adalah bentuk sequance diagram barang keluar dari Aplikasi Pengelolaan Inventaris Barang Pada SMK Negeri 1 Plampang.

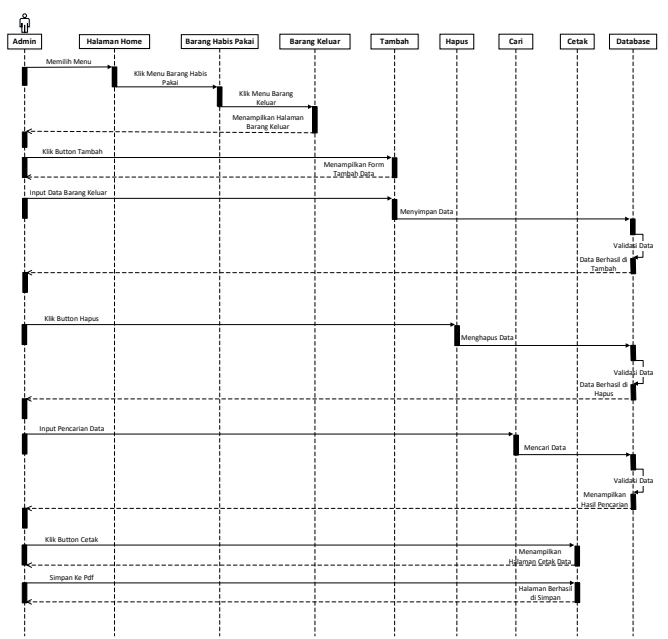

Gambar 4.11 Sequence Diagram Barang Keluar Proses ini dimulai ketika admin membuka halaman barang keluar dari barang habis pakai, maka sistem akan menampilkan halaman barang keluar. Lalu admin dapat mengelolah data dari barang keluar seperti menambah data, mengubah data, menghapus data, mencari data, dan mencetak data.

e. Sequence Diagram Barang

Berikut adalah bentuk sequance diagram barang dari Aplikasi Pengelolaan Inventaris Barang Pada SMK Negeri 1 Plampang.

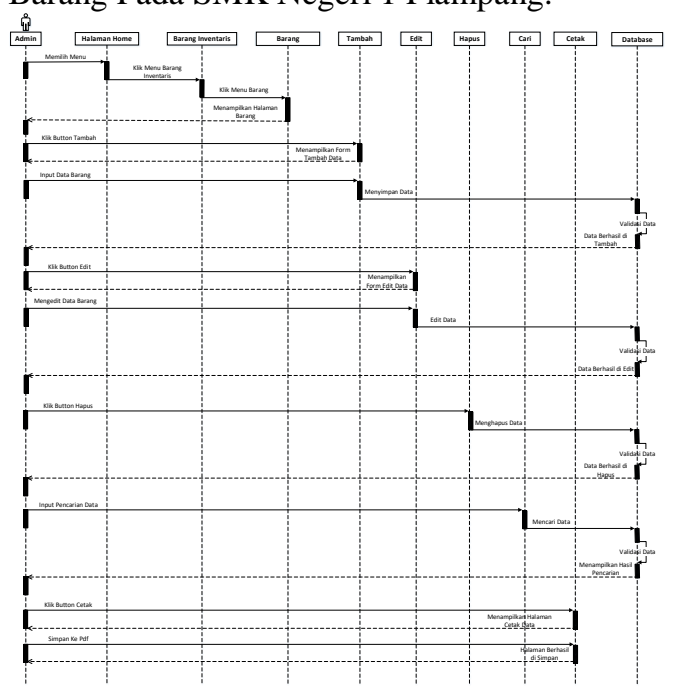

Gambar 12 Sequence Diagram Barang

Proses ini dimulai ketika admin membuka halaman barang dari barang inventaris, maka sistem akan menampilkan halaman barang. Lalu admin dapat mengelolah data dari barang seperti menambah data, mengubah data, menghapus data, mencari data, dan mencetak data.

f. Sequence Diagram Pendataan Barang Berikut adalah bentuk sequance diagram pendataan barang dari Aplikasi Pengelolaan Inventaris Barang Pada SMK Negeri 1 Plampang. 


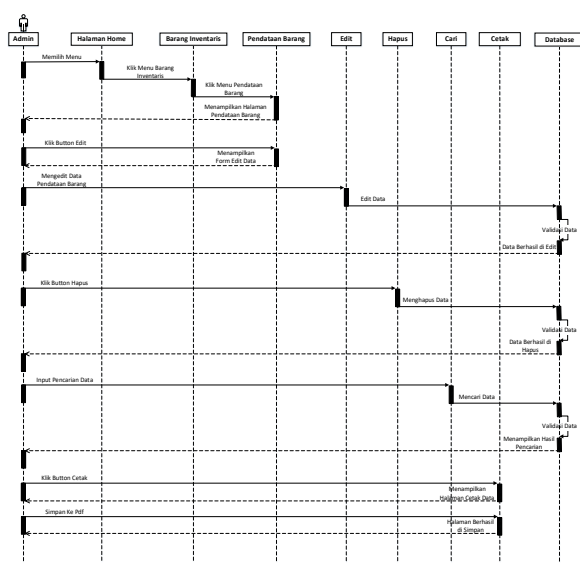

Gambar 13 Sequence Diagram Pendataan Barang Proses ini dimulai ketika admin membuka halaman pendataan barang dari barang inventaris, maka sistem akan menampilkan halaman pendataan barang. Lalu admin dapat mengelolah data dari pendataan barang seperti mengubah data, menghapus data, mencari data, dan mencetak data.

\section{Class Diagram}

Class diagram adalah diagram yang digunakan untuk menampilkan beberapa kelas yang ada dalam sistem perangkat lunak. Class diagram menunjukkan hubungan antar class dalam sistem yang sedang dibangun dan bagaimana mereka saling berkolaborasi untuk mencapai suatu tujuan.
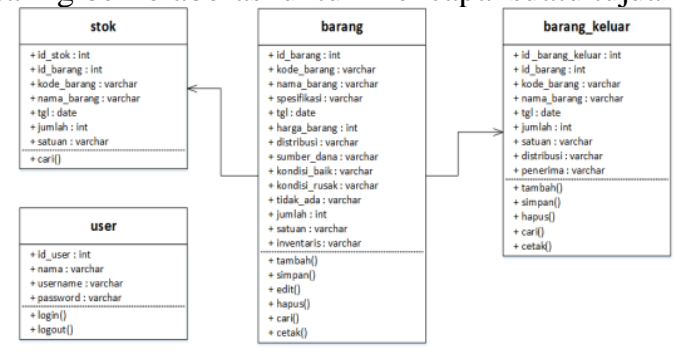

Gambar 14 Class Diagram Pengelolaan Inventaris Barang Di SMK Negeri 1 Plampang

5. Rancangan Struktur Database

Adapun rancangan struktur database dari Aplikasi Pengelolaan Inventaris Barang di SMK Negeri 1 Plampang sebagai berikut:

a. Tabel User

Nama Tabel : user

Primary Key : id_user

Foreign Key : :

Tabel 3 User

\begin{tabular}{|l|l|l|l|l|}
\hline No & $\begin{array}{l}\text { Field } \\
\text { Name }\end{array}$ & Type & Size & Description \\
\hline 1 & id_user & Int & 11 & Id User \\
\hline 2 & nama & Varchar & 35 & Nama User \\
\hline 3 & username & Varchar & 30 & $\begin{array}{l}\text { Nama } \\
\text { Administrator }\end{array}$ \\
\hline 4 & password & Varchar & 30 & $\begin{array}{l}\text { Password } \\
\text { Administrator }\end{array}$ \\
\hline
\end{tabular}

b. Tabel Stok Barang

Nama Tabel : stok

Primary Key : id_stok

Foreign Key : id_barang
Tabel 4 Stok Barang

\begin{tabular}{|c|c|c|c|c|}
\hline No & Field Name & Type & Size & Description \\
\hline 1 & id_stok & Int & 11 & $\begin{array}{c}\text { Id Stok } \\
\text { Barang }\end{array}$ \\
\hline 2 & id_barang & Int & 11 & Id Barang \\
\hline 3 & kode_barang & Varchar & 35 & $\begin{array}{c}\text { Kode } \\
\text { Barang }\end{array}$ \\
\hline 4 & nama_barang & Varchar & 35 & $\begin{array}{c}\text { Nama } \\
\text { Barang }\end{array}$ \\
\hline 5 & tgl & Date & - & $\begin{array}{c}\text { Tgl Barang } \\
\text { Masuk }\end{array}$ \\
\hline 6 & jumlah & Int & 11 & $\begin{array}{c}\text { Jumlah } \\
\text { Barang }\end{array}$ \\
\hline 7 & satuan & Varchar & 25 & $\begin{array}{c}\text { Satuan } \\
\text { Barang }\end{array}$ \\
\hline
\end{tabular}

c. Tabel Barang Keluar

Nama Tabel : barang_keluar

Primary Key : id_barang_keluar

Foreign Key : id_barang

Tabel 5 Barang Keluar

\begin{tabular}{|c|c|c|c|c|}
\hline $\mathbf{N}$ & Field Name & Type & $\begin{array}{c}\text { Siz } \\
\text { e }\end{array}$ & $\begin{array}{c}\text { Descriptio } \\
\text { n }\end{array}$ \\
\hline 1 & $\begin{array}{c}\text { id_barang_kelu } \\
\text { ar }\end{array}$ & Int & 11 & $\begin{array}{c}\text { Id Barang } \\
\text { Keluar }\end{array}$ \\
\hline 2 & id_barang & Int & 11 & Id Barang \\
\hline 3 & kode_barang & $\begin{array}{c}\text { Varcha } \\
\mathrm{r}\end{array}$ & 35 & $\begin{array}{c}\text { Kode } \\
\text { Barang }\end{array}$ \\
\hline 4 & nama_barang & $\begin{array}{c}\text { Varcha } \\
\mathrm{r}\end{array}$ & 50 & $\begin{array}{c}\text { Nama } \\
\text { Barang }\end{array}$ \\
\hline 5 & $\operatorname{tgl}$ & Date & - & $\begin{array}{c}\text { Tgl Barang } \\
\text { Keluar }\end{array}$ \\
\hline 6 & jumlah & Int & 11 & $\begin{array}{l}\text { Jumlah } \\
\text { Barang } \\
\text { Keluar }\end{array}$ \\
\hline 7 & satuan & $\begin{array}{c}\text { Varcha } \\
\mathrm{r}\end{array}$ & 25 & $\begin{array}{l}\text { Satuan } \\
\text { Barang }\end{array}$ \\
\hline 8 & distribusi & $\begin{array}{c}\text { Varcha } \\
\mathrm{r}\end{array}$ & 50 & $\begin{array}{c}\text { Distribusi } \\
\text { Barang } \\
\text { Keluar }\end{array}$ \\
\hline 9 & penerima & $\begin{array}{c}\text { Varcha } \\
\mathrm{r}\end{array}$ & 35 & $\begin{array}{c}\text { Penerima } \\
\text { Barang } \\
\text { Keluar }\end{array}$ \\
\hline
\end{tabular}

d. Tabel Barang

Nama Tabel : barang

Primary Key : id_barang

Foreign Key : : -

\begin{tabular}{|c|c|c|c|c|}
\hline No & Field Name & Type & Size & Description \\
\hline 1 & id_barang & Int & 11 & Id Barang \\
\hline 2 & kode_barang & Varchar & 35 & $\begin{array}{c}\text { Kode } \\
\text { Barang }\end{array}$ \\
\hline 3 & nama_barang & Varchar & 50 & $\begin{array}{c}\text { Nama } \\
\text { Barang }\end{array}$ \\
\hline 4 & spesifikasi & Varchar & 50 & $\begin{array}{c}\text { Spesifikasi } \\
\text { Barang }\end{array}$ \\
\hline 5 & tgl & Date & - & $\begin{array}{c}\text { Tgl Barang } \\
\text { Masuk }\end{array}$ \\
\hline 6 & harga_barang & Int & 30 & Harga \\
\hline
\end{tabular}




\begin{tabular}{|c|c|c|c|c|}
\hline & & & & Barang \\
\hline 7 & distribusi & Varchar & 50 & $\begin{array}{c}\text { Distribusi } \\
\text { Barang }\end{array}$ \\
\hline 8 & sumber_dana & Varchar & 50 & $\begin{array}{c}\text { Sumber } \\
\text { Dana }\end{array}$ \\
\hline 9 & kondisi_baik & Int & 11 & $\begin{array}{c}\text { Jumlah } \\
\text { Barang } \\
\text { Baik }\end{array}$ \\
\hline 10 & kondisi_rusak & Int & 11 & $\begin{array}{c}\text { Jumlah } \\
\text { Barang } \\
\text { Rusak }\end{array}$ \\
\hline 11 & tidak_ada & Int & 11 & $\begin{array}{c}\text { Jumlah } \\
\text { Barang } \\
\text { Yang Sudah } \\
\text { Tidak Ada }\end{array}$ \\
\hline 12 & jumlah & Int & 11 & $\begin{array}{l}\text { Jumlah } \\
\text { Barang }\end{array}$ \\
\hline 13 & satuan & Varchar & 25 & $\begin{array}{l}\text { Satuan } \\
\text { Barang }\end{array}$ \\
\hline 14 & inventaris & Varchar & 5 & $\begin{array}{c}\text { Kategori } \\
\text { Barang } \\
\text { (Habis } \\
\text { Pakai \& } \\
\text { Inventaris) }\end{array}$ \\
\hline
\end{tabular}

6. Implementasi Interface

Adapun implementasi interface dari Aplikasi Pengelolaan Inventaris Barang di SMK Negeri 1 Plampang adalah sebagai berikut:

a. Implementasi Tampilan Halaman Login

Adapun bentuk implemetasi dari perancangan tampilan halaman login adalah sebagai berikut.

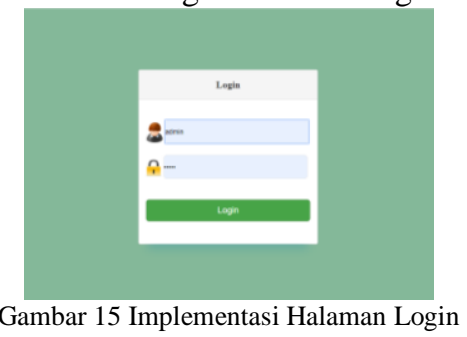

Implementasi halaman login ini merupakan halaman pertama yang akan muncul ketika admin melakukan pemanggilan aplikasi, pada halaman ini admin harus melakukan login dengan mengisi username dan password untuk dapat mengakses ke dalam aplikasi.

b. Implementasi Tampilan Halaman Home Adapun bentuk implemetasi dari perancangan tampilan halaman home adalah sebagai berikut.

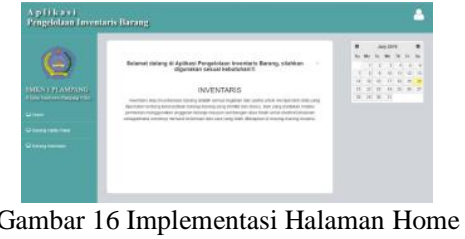

Implementasi tampilan halaman home ini adalah halaman utama yang tampil ketika admin berhasil login.

c. Implementasi Tampilan Halaman Barang Masuk
Adapun bentuk implemetasi dari perancangan tampilan halaman barang masuk dari barang habis pakai adalah sebagai berikut.

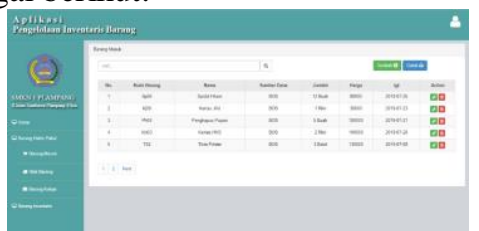

Gambar 17 Implementasi Halaman Barang Masuk Dari implementasi halaman barang masuk ini admin dapat melihat dan mengelolah data seperti menambah data, mengedit data, menghapus data, mencari data dan mencetak data.

d. Implementasi Tampilan Halaman Stok Barang

Adapun bentuk implemetasi dari perancangan tampilan halaman stok barang dari barang habis pakai adalah sebagai berikut.

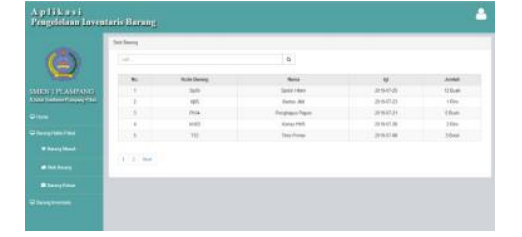

Gambar 18 Implementasi Halaman Stok Barang Dari implementasi halaman stok barang ini admin hanya dapat melihat melakukan pencarian data saja.

e. Implementasi Tampilan Halaman Barang Keluar

Adapun bentuk implemetasi dari perancangan tampilan halaman barang keluar dari barang habis pakai adalah sebagai berikut.

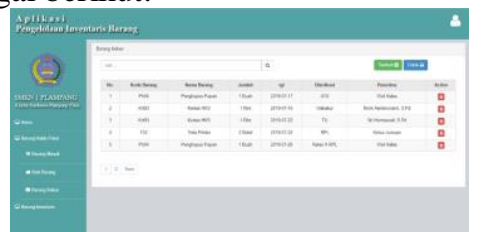

Gambar 19 Implementasi Halaman Barang Keluar Dari implementasi halaman barang keluar ini admin dapat melihat dan mengelolah data seperti menambah data, menghapus data, mencari data dan mencetak data.

f. Implementasi Tampilan Halaman Barang Adapun bentuk implemetasi dari perancangan tampilan halaman barang dari barang inventaris adalah sebagai berikut.

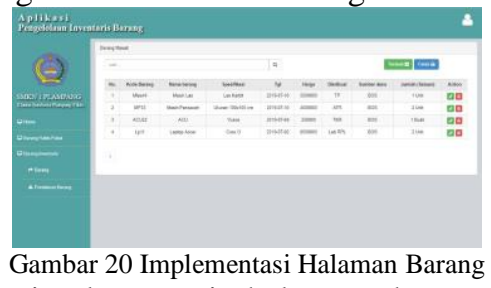

Dari implementasi halaman barang ini admin dapat melihat dan mengelolah data seperti menambah data, mengedit data, menghapus data, mencari data dan mencetak data. 
g. Implementasi Tampilan Halaman Pendataan Barang

Adapun bentuk implemetasi dari perancangan tampilan halaman pendataan barang dari barang inventaris adalah sebagai berikut.

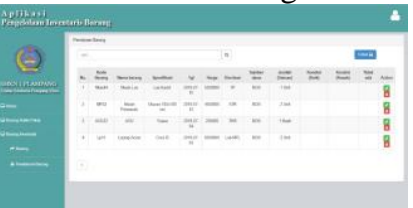

Gambar 21 Implementasi Halaman Pendataan Barang Dari implementasi halaman pendataan barang ini admin dapat melihat dan mengelolah data seperti mengedit data, menghapus data mencari data dan mencetak data.

7. Pengujian Perangkat Lunak (Black Box) Adapun hasil pegujian dari perangkat lunak yang dilakukan menggunakan pengujian black box.

a. Pengujian Halaman Login

Berikut adalah pengujian halaman login pada aplikasi pengelolaan inventaris barang di SMK

Negeri 1 Plampang.

Tabel 7 Pengujian Halaman Login

\begin{tabular}{|c|c|c|c|c|}
\hline \multicolumn{5}{|c|}{ Kasus dan Hasil Uji } \\
\hline No & $\begin{array}{c}\text { Aksi } \\
\text { Actor }\end{array}$ & Harapan & $\begin{array}{c}\text { Hasil } \\
\text { Pengamatan }\end{array}$ & $\begin{array}{c}\text { Kesim } \\
\text { pulan }\end{array}$ \\
\hline 1 & $\begin{array}{l}\text { Meng } \\
\text { akses } \\
\text { halam } \\
\text { an } \\
\text { login }\end{array}$ & $\begin{array}{l}\text { Menampi } \\
\text { lkan } \\
\text { halaman } \\
\text { login }\end{array}$ & $\begin{array}{l}\text { Pada tampilan } \\
\text { login ini } \\
\text { terdapat } \\
\text { username dan } \\
\text { password yang } \\
\text { dapat di isi } \\
\text { sebelum } \\
\text { masuk } \\
\text { dalam } \\
\text { halaman } \\
\text { admin untuk } \\
\text { melakukan } \\
\text { pengelolaan } \\
\text { data. }\end{array}$ & Valid \\
\hline
\end{tabular}

b. Pengujian Halaman Admin

Berikut adalah pengujian menu halaman admin pada aplikasi pengelolaan inventaris barang di SMK Negeri 1 Plampang.

\begin{tabular}{|c|c|c|c|c|}
\hline \multicolumn{5}{|c|}{ Kasus dan Hasil Uji } \\
\hline No & $\begin{array}{c}\text { Aksi } \\
\text { Actor }\end{array}$ & Harapan & $\begin{array}{c}\text { Hasil } \\
\text { Pengamat? }\end{array}$ & $\begin{array}{c}\text { Kesim } \\
\text { pulan }\end{array}$ \\
\hline 1 & $\begin{array}{l}\text { Meng } \\
\text { klik } \\
\text { butto } \\
\mathrm{n} \\
\text { menu } \\
\text { home } \\
\text { atau } \\
\text { Meng }\end{array}$ & $\begin{array}{l}\text { Menampi } \\
\text { lkan } \\
\text { halaman } \\
\text { utama }\end{array}$ & $\begin{array}{l}\text { Pada tampi } \\
\text { home } \\
\text { terdapat } \\
\text { beberapa }\end{array}$ & Valid \\
\hline
\end{tabular}

\begin{tabular}{|c|c|c|c|c|}
\hline & $\begin{array}{l}\text { akses } \\
\text { halam } \\
\text { an } \\
\text { utama }\end{array}$ & & $\begin{array}{l}\text { menu seperti } \\
\text { menu home, } \\
\text { menu barang } \\
\text { habis pakai } \\
\text { (barang } \\
\text { masuk, stok } \\
\text { barang, barang } \\
\text { keluar) dan } \\
\text { menu barang } \\
\text { inventaris } \\
\text { (barang, } \\
\text { pendataan } \\
\text { barang). }\end{array}$ & \\
\hline 2 & $\begin{array}{l}\text { Meng } \\
\text { klik } \\
\text { butto } \\
\mathrm{n} \\
\text { menu } \\
\text { baran } \\
\mathrm{g} \\
\text { masu } \\
\mathrm{k} \\
\text { yang } \\
\text { terda } \\
\text { pat di } \\
\text { menu } \\
\text { baran } \\
\mathrm{g} \\
\text { habis } \\
\text { pakai }\end{array}$ & $\begin{array}{l}\text { Menampi } \\
\text { lkan data } \\
\text { barang } \\
\text { masuk }\end{array}$ & $\begin{array}{l} \\
\\
\text { Pada menu } \\
\text { barang masuk } \\
\text { akan } \\
\text { menampilkan } \\
\text { data dari } \\
\text { barang masuk } \\
\text { yang dapat di } \\
\text { kelolah oleh } \\
\text { admin seperti } \\
\text { tambah data, } \\
\text { edit data, } \\
\text { hapus data, } \\
\text { cari data, dan } \\
\text { cetak data. }\end{array}$ & Valid \\
\hline 5 & $\begin{array}{l}\text { Meng } \\
\text { klik } \\
\text { butto } \\
\mathrm{n} \\
\text { menu } \\
\text { stok } \\
\text { baran } \\
\mathrm{g} \\
\text { yang } \\
\text { terda } \\
\text { pat di } \\
\text { menu } \\
\text { baran } \\
\mathrm{g} \\
\text { habis } \\
\text { pakai }\end{array}$ & $\begin{array}{l}\text { Menampi } \\
\text { lkan data } \\
\text { stok } \\
\text { barang }\end{array}$ & $\begin{array}{l}\text { Pada menu } \\
\text { stok barang } \\
\text { hanya } \\
\text { menampilkan } \\
\text { data dari stok } \\
\text { barang saja. }\end{array}$ & Valid \\
\hline 6 & $\begin{array}{l}\text { Meng } \\
\text { klik } \\
\text { butto } \\
\mathrm{n} \\
\text { menu } \\
\text { baran } \\
\mathrm{g} \\
\text { kelua } \\
\mathrm{r} \\
\text { yang } \\
\text { terda } \\
\text { pat di } \\
\text { menu } \\
\text { baran } \\
\mathrm{g} \\
\text { habis } \\
\end{array}$ & $\begin{array}{l}\text { Menampi } \\
\text { lkan data } \\
\text { barang } \\
\text { keluar }\end{array}$ & $\begin{array}{l} \\
\end{array}$ & Valid \\
\hline
\end{tabular}




\begin{tabular}{|c|c|c|c|c|}
\hline & pakai & & cetak data. & \\
\hline 8 & $\begin{array}{l}\text { Meng } \\
\text { klik } \\
\text { butto } \\
\mathrm{n} \\
\text { menu } \\
\text { baran } \\
\mathrm{g} \\
\text { yang } \\
\text { terda } \\
\text { pat di } \\
\text { menu } \\
\text { baran } \\
\text { g } \\
\text { inven } \\
\text { taris }\end{array}$ & $\begin{array}{l}\text { Menampi } \\
\text { lkan data } \\
\text { barang }\end{array}$ & $\begin{array}{lr}\text { Pada menu } \\
\text { barang akan } \\
\text { menampilkan } \\
\text { data dari } \\
\text { barang yang } \\
\text { dapat } \\
\text { kelolah oleh } \\
\text { admin seperti } \\
\text { tambah data, } \\
\text { edit data, } \\
\text { hapus data, } \\
\text { cari data, dan } \\
\text { cetak data. }\end{array}$ & Valid \\
\hline 11 & $\begin{array}{l}\text { Meng } \\
\text { klik } \\
\text { butto } \\
\mathrm{n} \\
\text { menu } \\
\text { penda } \\
\text { taan } \\
\text { baran } \\
\mathrm{g} \\
\text { yang } \\
\text { terda } \\
\text { pat di } \\
\text { menu } \\
\text { baran } \\
\mathrm{g} \\
\text { inven } \\
\text { taris }\end{array}$ & $\begin{array}{l}\text { Menampi } \\
\text { lkan data } \\
\text { pendataa } \\
\text { n barang }\end{array}$ & $\begin{array}{l}\text { Pada menu } \\
\text { pendataan } \\
\text { barang akan } \\
\text { menampilkan } \\
\text { data dari } \\
\text { pendataan } \\
\text { barang yang } \\
\text { dapat di } \\
\text { kelolah oleh } \\
\text { admin seperti } \\
\text { tambah data, } \\
\text { edit data, } \\
\text { hapus data, } \\
\text { cari data, dan } \\
\text { cetak data. }\end{array}$ & Valid \\
\hline
\end{tabular}

\section{Kesimpulan dan Saran Kesimpulan}

Berdasarkan hasil penelitian dan pembahasan yang telah dilakukan, dapat disimpulkan bahwa:

1. Dengan adanya aplikasi ini dapat membantu karyawan tata usaha di SMK Negeri 1 Plampang dalam melakukan pengelolaan data barang seperti memudahkan dalam pencarian data dan saat pembuatan laporan.

2. Fitur-fitur yang dimiliki oleh aplikasi ini yaitu mengelolah data barang seperti mencari, menambah, mengedit, menghapus, dan mencetak data.

\section{Saran}

Berdasarkan kesimpulan diatas, maka saran yang diharapkan yaitu dilakukan pengembangan aplikasi pengelolaan inventaris barang seperti menambah fitur upload gambar/foto pada halaman pendataan barang dan menambah fitur print laporan berdasarkan tahun yang diinginkan.

\section{Daftar Pustaka}

1. Afifiddin. 2010. Pengantar Administrasi Pembangunan. Bandung: Alvabeta.

2. Arief, M.Rudianto. 2011. Pemrograman Web Dinamis Menggunakan Php dan Mysql. Yogyakarta: Andi.

3. Hendy, Dwi Nugroho. 2018. Pengembangan Sistem Informasi Inventaris Barang Berbasis Website di SMK Piri 2 Yogyakarta. Jurnal Teknologi dan Sistem Informasi, Vol. 1, No.5, hlm. 89. Tanggal Akses: 25 Maret 2019.

4. Kurniawan, A. (2012). Rekayasa Perangkat Lunak Aplikasi Penjualan Pada Toko Story Time Factory Outlet Menggunakan Pemrogram Java. Jurnal, Universitas Andalas, hlm. 3. Tanggal Akses : 28 Maret 2019.

5. Pressman, R.S. 2015. Rekayasa Perangkat Lunak : Pendekatan Praktisi Buku I. Yogyakarta: Andi.

6. Purwanto. 2009. Evaluasi Hasil Belajar. Yogyakarta: Pustaka Belajar.

7. Rusdiana, dan Moch. Irfan. 2014. Sistem Informasi Manajemen. Bandung: Pustaka Setia.

8. ShortCourse. 2011. Adobe Dreamweaver CS5 untuk Beragam Desain Website Interaktif. Yogyakarta: Andi

9. Sugiarti, Yuni. 2018. Dasar-dasar pemrograman JAVA Netbeans, Database, UML, dan Interface. Bandung: Rosdakarya.

10. Susanto, Wiwit. 2010. Pemrograman Dengan MySQL.Yogyakarta: Andi.

11. Sutarman. 2012. Pengantar Teknologi Informasi. Jakarta: Bumi Aksara.

12. Wahyu, Rezki Romadhon. 2014. Sistem Informasi Pengelolaan Barang Inventaris Berbasis Desktop di SMK Negeri 1 Sungailiat. Jurnal Teknologi dan Sistem Informasi, Vol. 1, No.5, hlm. 8. Tanggal Akses: 25 Maret 2019.

13. Widiapsari. 2011. Inventaris Pra dan Sarana Pendidikan Untuk Terwujudnya Tertib Administrasi. Diakses $10 \quad$ Maret $2019 \quad$ dari http://www.sma7malang.sch.id/index.php?option=c om_content\&view=article\&id=112:inventarisasipra-dan-sarana-pendi-dikan-untuk-terujudnya-tertibadministrasi\&catid=34;teknologi-informasi-akomunikasi\&|temid=34

14. Wikipedia. Xampp. Diakses 21 Maret 2019 dari https://id.wikipedia.org/wiki/XAMPP

15. Yakub. 2012. Pengantar Sistem Informasi. Yogyakarta: Graha Ilmu.

16. Yuhefizar, H. Mooduto dan R. Hidayat. 2009. Cara Mudah Membangun Website Interaktif. Jakarta: Elex Media Komputindo. 